\title{
The Bible and ethics: Pathways for dialogue
}

Author:
Volker Rabens ${ }^{1,2}$
Affiliations:
'Faculty of Theology,
University of Jena, Germany
'Unit for Reformed Theology,
Faculty of Theology,
North-West University,
South Africa
Corresponding author:
Volker Rabens,
v.rabens@gmx.net
Dates:
Received: 17 Feb. 2017
Accepted: 20 Mar. 2017
Published: 31 May 2017
mobila device
to read online.
How to cite this article:
Rabens, V., 2017, 'The Bible
and ethics: Pathways for
dialogue', In die Skriflig 51(3),
a2138. https://doi.
org/10.4102/ids.v51i3.2246
Copyright:
C 2017. The Authors.
Licensee: AOSIS. This work
is licensed under the
Creative Commons
Attribution License.

The potential relevance of biblical ethics for today is a contested issue. What is the significance of individual ethical texts of the Bible, and how - if at all - can they be dialogue partners for the ethical discourses of the 21st century? This article suggests and discusses a number of interpretative steps on the way towards a fruitful dialogue between the biblical text and contemporary concerns of religious-ethical life. After some introductory remarks on the use of the Bible in a Christian context, the article submits six different parameters of practical hermeneutics in two sections: 1 . Text and culture; and 2. Text and canon. From the perspective of the parameter of canonical centrality, for example, it is argued that the biblical narrative of love, as it culminates in the gospel of Jesus Christ, stands out as a primus inter pares reference point for the dialogue between biblical ethics and ethics today. In the course of a nuanced discussion of these hermeneutical parameters, the article also provides a critical review of a number of alternative proposals on the relationship of the Bible and ethics.

\section{Introduction}

The potential relevance of biblical ethics for today is a contested issue. What is the significance of individual ethical texts of the Bible ${ }^{1}$ and how - if at all - can they be dialogue partners for the ethical discourses of the 21st century? Jan van der Watt, to whom this article is dedicated in thankfulness for his scholarship and friendship, is an important voice in contemporary scholarship on biblical ethics. For example, in 2006 he has published a comprehensive 660-page volume collecting contributions by specialists dealing with the issues of identity, ethics and ethos in the various books of the New Testament (Van der Watt 2006b). In his concluding chapter, Van der Watt draws together some of the insights gained on the basis of the different essays. He (Van der Watt 2006a) explains that

By analyzing the different books, as was done in this volume, a basic framework with important indicators emerged [of the Christologically interpreted Torah, not as rule system, but interpreted in love, as an expression of relations between God and people and people amongst themselves, p. 632] that serves as an authoritative base for the ethical applications. This might enable us to establish trajectories that could aid us in our further ethical deliberations. (p. 629)

The value of such a grand picture of the various ethical voices in the New Testament cannot be overestimated. In this article, the intention is to tap into some of the insights gained from such a broad study of the biblical canon. However, the starting point of this article is not this broader framework, but the individual biblical text and its potential ethical implications. In the German university context where I teach New Testament, a compulsory course of the theology degree is 'Methods in New Testament Exegesis', the so-called 'Proseminar' that is regularly offered every semester. It walks through the different steps of critical engagement with a New Testament text from synchronic and diachronic perspectives. Textbooks abound (see e.g. the recent Finnern \& Rüggemeier 2016). For most of these textbooks the task is accomplished once the exegetical steps have been applied. They leave the students with the results of the historical-critical inquiry and do not suggest methodological steps for moving on from there. By contrast, several AngloAmerican textbooks provide guidance on how the text may be contextualised or 'applied' today. It is therefore no surprise that the two graphic illustrations presented in the course of this article are taken from this latter body of literature. The majority of textbooks produced in the tradition of German-speaking scholarship focuses on biblical interpretation as a historical (and theological) inquiry into the formative period of the New Testament and the Early Church. The complex hermeneutical task of discerning the potential relevance of individual biblical passages for Christian ethics today is often left to (rather than undertaken together with) the other theological

\footnotetext{
1.When speaking about 'ethical texts of the Bible', the intention is not to suggest that the Bible offers a systematic analysis of the grounds motives, forms and goals of moral conduct. From a systematic perspective one would rather need to speak of 'implicit (biblical) ethics'. However, if employed in its everyday sense, 'ethics' is clearly a concern of various texts in the Bible that implicitly or explicitly give evidence of some 'reflective consideration of behavioural decisions and - more generally speaking - of life with a view towards their guiding norms and the goal of an evaluation' (thus the definition of ethics by Zimmermann 2013:3).
} 
disciplines of systematic and practical theology as well as ethics. It is hence a daunting task for a biblical scholar to chart potential paths between the Bible and ethics. What is offered here are merely a number of reflections in dialogue with those who have walked the path before (for overviews of previous endeavours, see inter alia Hays 2006; Cosgrove 2011; Frevel 2015). After some introductory remarks on the use of the Bible in a Christian context, the article will suggest six different parameters of practical hermeneutics in two sections (1. Text and cultural context; and 2. Text and canonical context). In the course of a nuanced discussion of these pathways for a dialogue between the Bible and ethics, a critical review of a number of alternative proposals will also be provided.

\section{The Bible as ethical instruction for today}

'The Bible is the operating instruction for life.' This is a straightforward approach to using the Bible in Christian life that is taught in various churches and Christian communities around the globe. The reasoning behind this approach is straightforward too: 'God has created us and he knows best how we should live ("for best results, follow the Maker's instructions"). In the Bible he tells us how to do so.' Arguments like these are built on Bible verses such as 2 Timothy 3:

All scripture is inspired by God and useful for teaching, for reproof, for correction, and for training in righteousness, so that everyone who belongs to God may be proficient, equipped for every good work. (v. 16)

On this basis, Christians are asked to turn to the words of Scripture when they seek ethical guidance for themselves and the world. Many demand that the commands of Scripture need to be obeyed even if one's inclinations suggest otherwise. The potential consequences of such an approach to the Bible and ethics are well illustrated by the words of the 19th-century Episcopal bishop, John Henry Hopkins, who could not bring himself to accept an abolitionist stance on slavery:

If it were a matter to be determined by personal sympathies, tastes, or feelings, I should be as ready as any man to condemn the institution of slavery, for all my prejudices of education, habit, and social position stand entirely opposed to it. But as a Christian ... I am compelled to submit my weak and erring intellect to the authority of the Almighty. For then only can I be safe in my conclusions. (cited by Harrill 2006:vii)

Like Hopkins, many Christians today feel that if they root their conclusions for a contemporary ethic within the concrete specificity of the biblical text, such a move has the approval of God and thus provides the safety they are looking for. However, the fact that this approach seems to require the conclusion that scriptural passages such as Exodus 21:20-21 ('When a slave-owner strikes his slave ... with a rod and the slave ... survives a day or two, there is no punishment') suggest that God's will - past and present - is that keeping or even beating a slave is no crime, has rightly led some readers of Scripture to doubt the validity of this interpretative strategy.
The recognition of this dilemma has helped to raise the awareness for the need to investigate the presuppositions that we bring to the biblical text and its potential implications for religious-ethical life today. Therefore, this article will suggest and discuss a number of interpretative steps on the way towards a more fruitful dialogue between the biblical text and contemporary ethics.

A fundamental problem with approaching the Bible as 'operating instruction for life' is the fact that the Bible is not an instructional manual. It is a different genre. In fact, it is a library of books with many different genres: poems, prophecies, parables, stories, histories, letters, et cetera. In the same way as we need to know the rules of different ball games such as football, basketball and rugby in order to understand the game, we should also be familiar with the parameters of interpretation of each genre to safeguard against serious misinterpretation. Approaching Scripture as operating instructions or as a legal constitution makes the Bible into something which it is not: a manual with uniform eternal truths. An operation manual of a CD-player tells the user in one sentence how to start playing a $\mathrm{CD}$. There is only one way of doing so, namely by pressing 'play'. The Bible, however, not only contains many different genres in which non-literal language abounds (spoken not to 'us' but to a different audience with a different culture of long ago). The Bible is also deliberately diverse. Both Testaments of the Bible start with more than one primal story: two creation stories and four Jesus-stories. Also on explicitly ethical issues, such as the attitude towards violence, we find not just one stance, but multiple perspectives (see e.g. Dt 20:10-18; Jos 6:1721; 1 Sm 15; Mt 5:43-45; 1 Pt 2:12-14).

Nevertheless, believers may want to add an important piece to the mosaic of Scripture: its inspiration. As mentioned above, divine inspiration is explicitly attributed to the (Hebrew) Bible in 2 Timothy 3:16 (cf. 2 Pt 1:20-21). This quality of Scripture is conveyed by the word $\theta \varepsilon$ ó $\pi v \varepsilon v \sigma \tau o \varsigma$ [lit. God-breathed/inspired; used only here in the Bible]. It does not provide any details about the process or nature of inspiration. However, the result of inspiration is clearly and

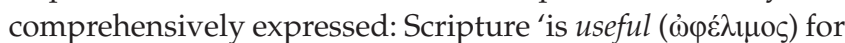
teaching ..., for training in righteousness, so that everyone ... may be proficient, equipped for every good work'. Due to its inspiration, Scripture is useful and valuable as we try to determine what Christian ethics should look like. One aim of this article is to explore different avenues of how this positive potential of Scripture can be utilised and tapped into by interpretative communities today. However, inspiration certainly does not convert a portable library into an inspired legal constitution. In contrast to an authoritative constitution, which preserves enforceable agreements, an authoritative library preserves key stories and arguments that need to be heard in their individual contexts and brought into conversation with one another, and with the modern readers and their respective contexts. It seems, then, that an instant application of every individual passage of Scripture to today's ethical concerns does not grant the absolute certainty to do the divine will so intensely sought after by Hopkins and many modern readers like him. 
Due to the hermeneutical complexities involved in trying to fathom the relevance of individual biblical passages for religious-ethical life, some ethicists have decided to reduce the diversity of the ethical statements in the Bible to the love command. In the Christian approach to morality called 'situation ethics', love is elevated to be the single guiding principle for all situations of ethical pertinence (see e.g. Fletcher 1966). This is an attractive solution that certainly seems to reduce the hermeneutical complexities. For instance, it seems to obviate the meticulous historical study that is necessary to understand what an ethical command in the Bible may have meant in its original context. Instead, this ethical approach seems to manage to rid the biblical commands of their cultural ballast and to distil the very essence of biblical ethics into a single principle. Nevertheless, this methodology is problematic. It reveals our modern desire for abstract, timeless principles. The Bible, however, is so much richer and has so much more inspirational potential than a single concept. It has inspired many admirable (religious, ethical and political) movements such as the fight for equality and the abolition of slavery by people like William Wilberforce, Martin Luther King and others. If all we have is a single (love) principle by which all ethical challenges need to be judged, it will oftentimes be very hard to discern what ultimately is the most loving thing to do - partly because it is impossible to estimate what the long-term consequences of our decisions might be. Moreover, if one defines love in utilitarian terms (the greatest happiness for the greatest number), one will seek in any moral situation to calculate the aggregate maximal utility of all concerned. But who are 'all concerned' - one's peers and family or society as a whole? The love-principle alone does not provide the necessary answers. Also the Bible does not give pat answers to the ethical challenges of today. However, its various stories and examples (most prominently that of Jesus) offer practical (case-based) knowledge as well as potential paradigms for developing a Christian ethos that may inspire fresh expressions of religious-ethical life today.

\section{Text and culture}

How can we take inspiration from Scripture for ethical issues today without reading into the Bible what we want it to say? In order to decide upon the potential voice of a particular ethical text for moral discourses in the 21st century, one first of all needs to try to understand the passage from the perspective of its original context. In addition to the various textbooks on exegetical methods that provide guidelines for interpretation, ${ }^{2}$ one may turn to Zimmermann's recently developed model (2009) for analysing the 'implicit ethics' of a text (from the perspectives of linguistic form, norms for action, history of traditions of individual norms, priorities of norms and values, ethical reflection, moral agent, reflected ethos, and range of influence). ${ }^{3}$ Approaching a text with

\footnotetext{
2.Compare Van der Watt's comprehensive 'exegetical wheel' diagram (2018) which provides an overview of the different methods of inquiry that can be applied in accordance with the particular features of the text to be interpreted.

3.Compare Zimmermann (2018) and the responses by Charles Cosgrove and Markus Zehnder in the same volume. See also the critical discussion and practical application of the model to the study of ethics in Galatians in Rabens (2014)
}

analytical categories like these in mind has the potential of uncovering various ethical aspects of a text that may then be compared with other texts. However, at the most fundamental level one will approach the text by investigating its literary and cultural contexts (including early Jewish and GrecoRoman literature). From the perspective of the literary context, one has to discern, for instance, whether one is dealing with a descriptive text (which may or may not assume to be normative) or a prescriptive text. ${ }^{4}$ From the perspective of the cultural context, one needs to identify the differences between the cultural environment of the biblical audience and that of today. If there seems to be an unbridgeable gap between 'them' and 'us', some interpreters suggest that one should search for an overarching ethical principle in the text that may then be adequately applied in the contemporary context. Duvall and Hays (2005:179) have illustrated the steps of this 'interpretative journey' with the image of travelling (through time) from one town to another via a bridge (see Figure 1).

We will walk this journey by applying the interpretative steps to the biblical command to kiss one another - specified in Romans 16:16 as a 'holy kiss' ( $\varphi \imath \lambda \eta ́ \mu \alpha \tau \imath \dot{\alpha} \gamma i \omega$; cf. 1 Cor 16:20; 2 Cor 13:12; 1 Th 5:26) and in 1 Peter 5:14 as a 'kiss of love' (

- Step 1: Grasp the text in the biblical town. What did the text mean to the original audience?

In antiquity, the kiss ( $\varphi$ í $\eta \mu \alpha)$ was an expression of affection ( $\left.\varphi \imath \lambda^{\prime} \alpha\right)$ among family members and close friends ( $\varphi$ í $\left.\lambda \circ\right)$ and a gesture of respect and honour for persons of authority like the king. Kisses were given on the mouth, hands and feet, along with substitute kisses. The predominant context of

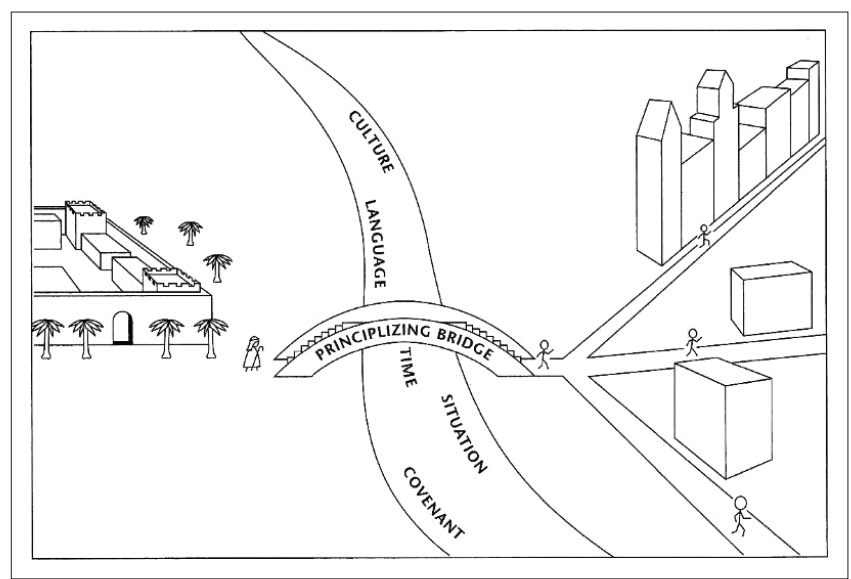

Source: Duvall and Hays (2005:179).

Figure 1: The Principlising Bridge.

4. Cosgrove (2002:69) differentiates various types of material with ethical relevance in the Bible, most prominently rules, principles and narratives. In narratives, characters play a specific, case-based role: the exemplary character acts in an exemplary way and is thus paradigmatic (of good, bad or morally mixed behaviour). The moral teaching of the Bible is also framed by a symbolic world that contains, according to Cosgrove (2002),

rules, principles, and paradigms, along with various assumptions about the nature of reality - assumptions that shape conceptions of what is possible, supply nature of reality assumptions that shape conceptions of what is possible, supply mives for ethical action, ans that it can be... Narrative caries prescriptive moral content only to the extent that it can be taken as offering a paradigm case. One must show from the narrative that a particular action is approved by the text, that is, held out as exemplary. (p. 69) 
kissing was not erotic. Kisses were exchanged at greeting and parting, making contracts, reconciliation, games, et cetera. It seems that Paul's designation of the kiss as 'holy' was something new. It may have referred to the proper attitude and holy motives of applying this gesture of unity within the church, challenging the audience to eliminate any mutual hostility in their midst (cf. Thrall 2000:912). 1 Peter qualifies this greeting as a 'kiss of love', bringing to the fore in summary form the whole of the epistle's teaching around the loving relations that demarcate the household of faith from the world where they felt estranged.

As ritual, the 'kiss of love' renews, strengthens, and recreates those patterns of thinking and feeling, that quality of life, determined by the merciful initiative of God who brings liberation in Christ and creates a household structured around his grace. (Green 2007:185)

- Step 2: Measure the width of the river to cross. What are the differences between the biblical audience and us?

In order to measure the gap between 'them' and 'us', one has to look at the praxis and the connotations of kissing today from the perspective of the specific (sub-)culture that is in focus. For example, in many West-European countries such as Germany, kissing (on the mouth) tends to have erotic connotations in various contexts. Kissing is also practiced in the family environment and in some (teenage) subcultures, though usually on the cheek. From this perspective, there is a considerable gap to be bridged between cultures where kissing was not predominantly associated with the erotic and cultures where romantic connotations abound.

- Step 3: Cross the principlising bridge. What is the theological principle in this text?

The idea behind the ó $\gamma 10 \varsigma$ or $\dot{\alpha} \gamma \alpha \dot{\alpha} \pi \eta$-kiss seems to have been to establish a (ritualised) gesture that expresses the belonging to a kinship-like group on a one-to-one level in the form of a warm-hearted greeting.

- Step 4: Grasp the text in our town. How should individual Christians today apply the theological principle in their lives?

'Shake hands warmly with each other.' That is how the Living Bible renders the Pauline command; and 'Give each other the handshake of Christian love' (1 Pt). This may be an appropriate application of the biblical command in a culture where a handshake is not the customary practice of greeting as, for example, in Germany. For the latter, a slightly less common gesture, such as a hug or a kiss on the cheek, may give a clearer expression to the special and potentially demarcating character that this gesture and ritual of expressing brotherly and sisterly love seems to have had in the Early Church (provided one wants to capture this potentially more exclusive aspect - a decision that would require an analysis of the relationship of church and society in the past and in the present).

More could be said about the community ethics of the 'holy kiss', but our purpose here is to illustrate and discuss a particular method of applying ethical texts of the Bible to today. What can we say about this 'principlising approach'? On the positive side, one of the strengths of this method is that it starts with the biblical text. It is hence concrete and seeks practical applications. However, it can be criticised that searching for abstract principles in every text maltreats the biblical canon as if it were a static deposit of timeless truths rather than appreciating the manifold voices expressed in various literary genres for what they are - and what they are not (cf. footnote 4 above). In contrast to a number of condensed ethical statements, such as Galatians 5:14, 19-24, many biblical texts or even entire books consist of narrative, poetry, proverbs, et cetera, that invite conversation rather than unquestioning obedience to the letter. As Flemming $(2005: 296,306)$ rightly stresses, the New Testament writings do more than provide a finished theological product. They model a process of doing theology in context, of engaging one's culture and offering one's audience a fresh and fitting articulation of the good news. The challenge for modern interpreters is therefore to be shaped not only by what the Bible says (the message), but also by what it does (the process of doing theology). The contextualising activity of the New Testament apostles and theologians by which they articulated the good news in specific historical and sociocultural circumstances that were usually very different from our own, can thus provide an example and a model of how contextual theologising may work today.

The 'interpretative journey' via the 'principlising bridge' is thus too narrow an approach and it is based on problematic assumptions about the nature of Scripture. As Cosgrove (2002:67) points out, the idea of 'applied biblical ethics' rests on a mistake if it means that there are biblical principles and normative concepts that can be accessed apart from applications. One cannot grasp the meaning of principles in the abstract apart from concrete cases (cf. Moxnes 1993:163164; Burridge 2007:356). Moreover, on the pathway towards a 'biblical ethics', these cases need to be related to other cases within the biblical canon. As we will see, individual ethical texts have to be read in the context of the narratives and paradigms of Scripture, such as God's liberating work in the exodus, in the Christ-event, et cetera. Apart from that, one also has to take into account that various ethical viewpoints (e.g. questions of purity) are nuanced differently in the different books and different parts of Scripture. We will return to this broader picture in section 2 .

Before an individual ethical text of the Bible is brought into dialogue with other canonical voices, we may first want to stay with the particular passage (which is our starting point in the current article) and investigate the text in its immediate literary and cultural context. It is also possible to start with situating the passage in its canonical context (cf. the introduction to section 2 below), but this runs the risk of missing the nuances of our text as we try to reflect on the similarities and differences between the ancient and modern cultures with respect to the ethical issues raised by our very text. So, what are the parameters of cultural embeddedness of the text that need to be analysed, weighed and put into conversation with the contemporary cultures of the text and 
of today? What is their bearing on the process of hermeneutical transfer? In order to find some tentative answers to these questions, the following four parameters of interpretation can serve as a set of initial guidelines that can direct us towards a promising pathway for a dialogue between the Bible and (modern) ethics. ${ }^{5}$

\section{a. Cultural particulars and underlying purpose}

The first avenue of inquiry draws attention to the relationship between the cultural particulars and the potential purpose of an ethical text. This parameter is not evidently discernible in every text, and - as in the case of (b-d) below - it should not be forced onto a text where this analytical category is not an easy fit. In cases where these parameters find an echo in the text, this guideline suggests that the purpose behind a biblical command carries greater weight than the cultural particulars of its application in the biblical context (cf. the emphasis on purpose in Mk 2:27). In contrast to the principlising approach, looking for the purpose behind a biblical text does not mean searching for timeless, 'supracultural' principles formulated in one-line statements. Rather, one is inquiring more broadly into the function of the text in the communicative situation of the original setting. In the case of the ó $\gamma \alpha \dot{\pi} \pi \eta$-kiss discussed above, interpreting the relevant passages from this perspective suggests that the purpose of expressing familial affection towards one another may inspire different ways of welcoming one another in different cultural contexts. Moreover, this parameter of interpretation is not used in isolation. There are cases where one's best construction of the rationale for a biblical command may uncover a set of cultural assumptions that one does not want to accept and may reject for other biblical-theological reasons. For instance, the ancient justification for the prohibition of adultery in the seventh commandment may include an assumption that husbands enjoy property rights in their wives - an assumption that we would reject on broader biblical-theological grounds. The parameter of purpose does not require that any or all of the assumptions contained in rule justifications must be accepted; 'it means only that the justifications are weightier than the rule qua rule' (Cosgrove 2002:50).

\section{b. Analogies between ancient and contemporary cultures}

In the course of establishing a dialogue between the Bible and contemporary Christian ethics, one will come across some instances of a notable degree of correspondence between the cultural context of a biblical text and our own. Such cases of analogy between the circumstances in the past and in the present invite a somewhat more straightforward transfer to today of the ethical guidance of Scripture (after the other interpretative moves outlined in this article have been made). For instance, in the case of Paul's command not to get drunk with wine (Eph 5:18), one may establish that the effects of drunkenness in antiquity were virtually the same as the

5.These and similar hermeneutical parameters have sometimes been introduced as somewhat fixed rules (cf. Osborne 2006:422-430; Strauss 2009:294-298). However somewhat fixed rules (cf. Osborne 2006:422-430; Strauss 2009:294-298). However,
see the nuanced and insightful discussion of these and further criteria of see the nuanced and insightful
interpretation in Cosgrove (2002). social and societal damages of alcoholism today (loss of control, poor judgement and a tendency toward physical or verbal abuse). Accordingly, we may conclude that the apostle's critical stance towards the abuse of alcohol can continue to function as a guideline for contemporary Christian ethics.

The parameter of analogy finds support and extended application in liberation theologian Clodovis Boff's category of 'correspondence of relationships' (1987). He looks at the similarities between the biblical text, which bears witness to the life and struggles of the people of God at a particular time and place in the past, and the contemporary situation and experience of a reader or community of readers. The contemporary state of affairs is understood as analogous to that of the antagonists in the (his)stories of the biblical books, and it may inform, inspire and challenge the readers of these stories. This inspiration and orientation is offered through models, types and paradigms (Boff 1987:146-50). To give an analogy from the Hebrew Bible: the prophet Nathan offered a story when he confronted David about Bathsheba and Uriah. Using moral imagination, people enter the particular story, place themselves in one or another role and then find themselves drawn or driven to particular courses of action. In Nathan's story, a rich man who steals a poor man's one lamb is analogous to a king who steals a man's wife and takes his life (2 Sm 12). David realises that the analogy is accurate and repents. As Gushee and Stassen (2016) point out, to make correct analogies,

we need to study the way the particular moral judgment/action functioned in the particular biblical context and then consider what moral judgment/action would function similarly in our context. No one can prove the adequacy of such a moral analogy, but we attempt moral analogies all the time. (p. 66)

\section{c. Cultural conformity and cultural limitation}

Some ethical texts in the Bible rest on scientific or cultural assumptions that are in tension with later scientific or cultural conventions. With regard to the former, it seems clear that certain scientific discoveries stand outside the scope of Scripture, of which some may have a bearing on ethics such as the (partly potentially medical) assumptions behind some of the Pentateuchal purity laws. This does not disqualify the Bible for the dialogue between sacred texts and current ethical concerns. As one may trust that Aristotle has something to teach us about ethics or that Aquinas has something to teach us about being a Christian without trusting them as a guide in scientific matters, so one may also trust the Bible for guidance in faith and practice without taking it as a guide on scientific questions (cf. Cosgrove 2002:150). ${ }^{6}$

With regard to the latter, the limited scope of the particulars of some ethical commands may come into focus when our

6.Nevertheless, it remains a matter of debate where the areas of science, faith and practice start to overlap. For example, in the context of his affirming stance towards practice start to overlap. For example, in the context of his affirming stance towards same-sex marriage, Loader (2016) argues that to truly honor Scripture and respect paul, we do better to acknowledge respectfully that we see Paul's understanding of human sexuality as no longer adequate. 'My faith does not commit me to firstcentury views about the universe, humanity, and sexuality which Paul and others assumed.' (p. 68) 
analysis of a biblical text's cultural context suggests that the author is operating within strong cultural or societal constraints. In the case of slavery, for example, what a number of interpreters would regard as Paul's failure to call for the full emancipation of slaves must be judged within a cultural context where to do so would have resulted in immediate arrest and execution. Such scenarios require a critical evaluation of the specific conventions and the culture-shaped ethical assumptions that come to the fore in the biblical text. However, such an evaluation needs to be done in a spirit of humility and critical self-reflection. Our latest scientific discoveries and our current cultural conventions have historically been shown repeatedly not be the last word on the matter. Apart from that, we will never know for sure whether (and if so, how) Paul would have written differently on the institution of slavery if he had lived in today's context with different economic conventions and other political pressures. In some cases, all we may want to do is attest that the views expressed by a biblical author agree with ancient cultural conventions, but not with the dominant trends in modern morality (be they religious or not). In other cases, detailed study may uncover a more nuanced, but perhaps also more tentative, opinion expressed in the text. It may leave room for the interpreter to draw out further implications leading on from those explicitly expressed in a text such as Paul's instructions to Philemon upon the return of his slave Onesimus. However, there are also cases where biblical authors disagree with the conventions of their cultural context and oppose the morality of popular philosophies or religious movements of their time. It is these cases of countercultural or 'prophetic' impetus to which we finally turn.

\section{d. Cultural and countercultural trends}

In contrast to the cultural conformity of some ethical positions found in the Bible, other biblical texts differ from the predominant views of the surrounding culture. ${ }^{7}$ Such difference may be taken as a sign of a significant biblical value or principle that should be accorded special weight in the dialogue between the Bible and Christian ethics today. A countercultural trend may be seen, for example, in Jesus' command to love one's enemies in Matthew 5:44 that runs contrary to the conventional wisdom of some of his contemporaries (vv. 43, 46-47; Plato, Meno, 71e, etc.; cf. Paul's instruction to husbands to model Christ's self-sacrificial love toward their wives in Eph 5:25). Taking up the positive impulses of liberation and feminist theologies, a number of scholars have defined the parameter of countercultural trends more narrowly as a presumption in favour of according greater weight to those countercultural tendencies in the Bible that express the voice of the powerless and the marginalised than to those tendencies that echo the dominant

7. Brueggemann (2005:71-72) calls these two tendencies in the (Hebrew) Scriptures iconic and aniconic. The former refers to consolidating tendencies based on a need for socil ander and typically involves a commitment to the status quo (as ane can frequently frequently witness in the purity and holiness traditions). The latter (aniconic prophetic side) regards socially transformative, liberative tendencies that mark out Israelite religion from its environment. voices of the culture (Cosgrove 2002:90; cf. Flemming 2005:308-310).

The parameter of identifying potential countercultural tendencies in a biblical text in relation to its cultural context is often combined with the aim of establishing 'trajectories' within the biblical canon that provide support as well as an interpretative direction for the individual countercultural tendencies. An example for such an endeavour is William Webb's model (2001) of searching for and engaging the redemptive spirit of a text in a way that moves the contemporary appropriation of the text beyond its original application. On this view, a sense of the redemptive spirit can be obtained by listening to how texts compare to their broader cultural milieu and how they sound within the unfolding of the canon. When taking the ancient text into our world, it is the redemptive spirit of Scripture that should inspire contemporary ethics (Webb 2001:30-31). For example, keeping and even beating a slave on the basis of verses like Exodus 21:20-21 would fail to take into account the countercultural movement of the text in its socio-economic context where beating a slave to death typically was no crime. Moreover, ignoring the redemptive movement of the text as well as key countercultural voices in its biblical context (such as G1 3:28; Phlm16-17, 21; 1 Cor 7:21-23; 12:13; cf. Lv 25:3943; Dt 23:15-16; etc.), and thus applying the text literally to today, would be a regressive movement - particularly from the perspective of many cultures today.

These potentially converse movements are illustrated by Webb with the diagram below (see Figure 2). The central position $(Y)$ stands for where the isolated words of the Bible are in their development of a subject. Then, on either side of the biblical text, one may ask the question of perspective: What could be our understanding of the biblical text if we try to look at it from the perspective of the original culture $(\mathrm{X})$ ? Also, what does the biblical text look like from the perspective of a contemporary culture that happens (at this point) to reflect a 'better' social ethic - one closer to an 'ultimate ethic' (Z) than to the ethic revealed in the isolated words of the biblical text? From one direction the Bible thus looks redemptive; from the other direction it appears regressive (Webb 2001:31-33; cf. the discussions in Marshall 2004 and Meadors 2009).

How are we to assess the parameter of countercultural trends, and more specifically Webb's 'redemptive-movement hermeneutic'? The strengths of this parameter of interpretation are both its concern to identify the dynamic potential of a particular text in its cultural context as well as its endeavour to read the text as part of a broader trajectory within the canon of Scripture. However, both these strengths are in need of some qualifications in order not to be misleading. Many aspects of biblical ethics seem to evade being assigned a point in a movement from $X$ to $Z$. If we take a central text of Paul's ethics as Philippians 2:5-11, for example, into what direction should we point the arrow of movement? The cruciform ethic that the community is to emulate is clearly countercultural, but does it move in a 


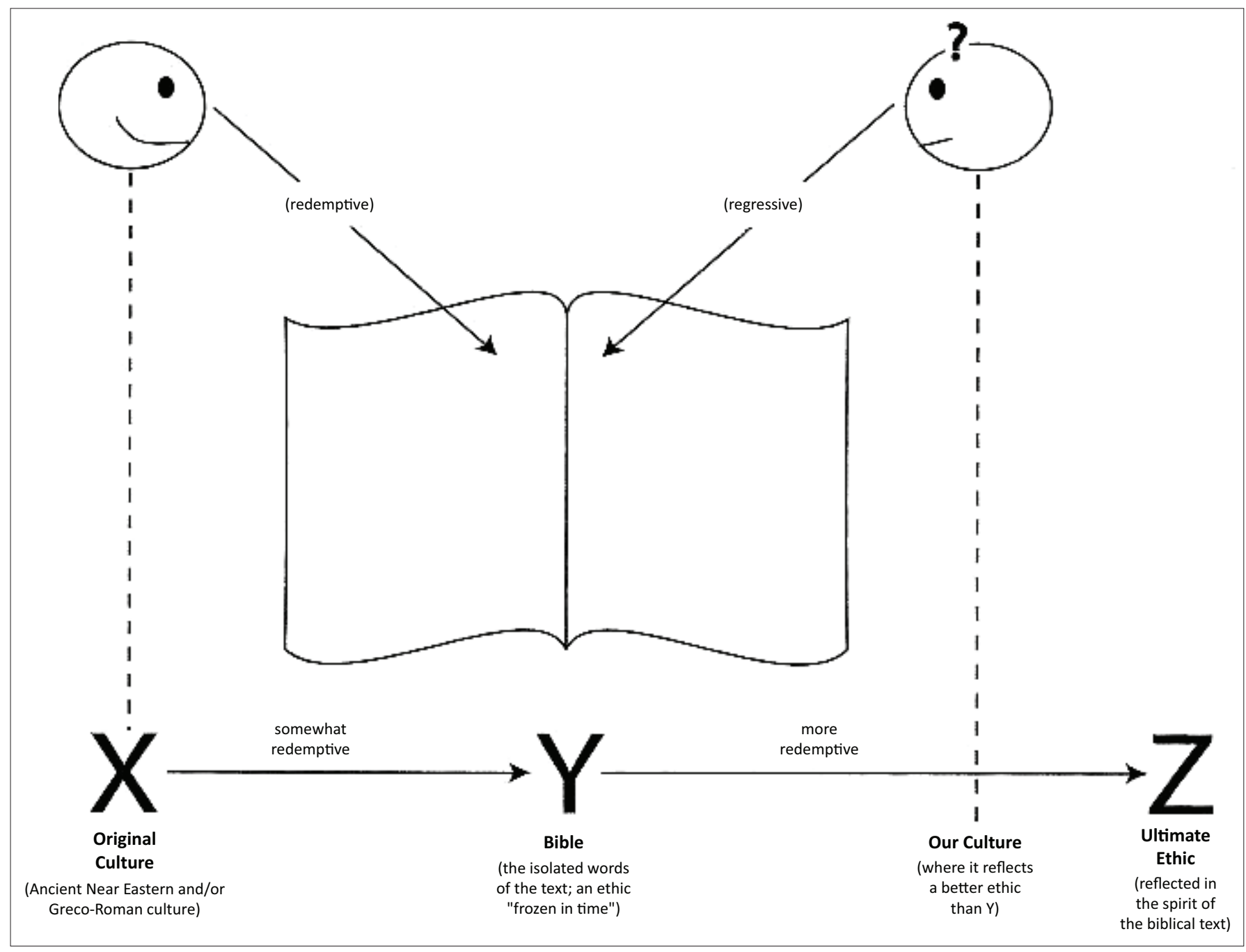

Source: Webb (2001:32)

Figure 2: Redemptive-Movement Hermeneutic.

'redemptive direction' towards modern ethics, developing further towards an 'ultimate ethic'?

For one thing, then, the concept of (countercultural) trends, movements and trajectories (which may be regarded as a subset of a salvation-historical or 'history of redemption' approach to biblical theology and ethics; cf. Klink III \& Lockett 2012:59-89) needs some qualifications so that it will not be misunderstood as the projection of progressive developmentalism onto the Bible. Otherwise, in a somewhat supercessionist demeanour, it would be legitimate to extrapolate from what one believes to be a developmental movement in the biblical tradition an endpoint that identifies a value or principle as being more normative than any stage along the trajectory. However, historical-critical demonstration of both particularity and heterogeneity in the Bible undermines many of the claims of progressive developments. While the general point of Webb's Slaves, Women and Homosexuals (2001) may be appreciated, a closer look at some of the movements that Webb identifies shows that they are at best a lot less linear than may be assumed. The newer passages dealing with the role of women are not necessarily the more liberative ones as a walk through the
Hebrew Bible or a study of the Pastoral Epistles indicates (cf. Meyers 2013; Goldingay 2018). Webb's diagram contains the danger of harbouring an idealist approach towards ethics in which the newer supersedes the older and moves on towards the 'ultimate'. However, developmental approaches need to take into account that the reality of 'biblical' history, as well as that of many religiously influenced societies today, is often at variance with the hope for continuous cultural progression on the path towards the realisation of the ultimate ethics (cf. e.g. the flourishing of human trafficking and sex slavery throughout [recent] history).

The fact that the biblical canon is pluralistic and presents different nuances on various topics such as violence, as well as the complex relationship of the two parts that make up the unity of the Christian canon (Hebrew Bible and New Testament), thus caution against adopting a straightforward developmentalist approach to the Scriptures. Nonetheless, this does not mean that there are no dominant themes, lines, continuities, unifying dynamics, overarching narratives, core witnesses, paradigms or trajectories (if the dominant image of the latter is not an arc with an endpoint of an 'ultimate ethic') in Scripture (cf. Cosgrove 2002:107-109; Brueggemann 
2005:710). In fact, it is an essential task of the interpreter seeking to ignite a dialogue between an ethical text in the Bible and the ethical concerns of contemporary culture not only to analyse the passage in its cultural context (and relate that to today), but also to situate it within its canonical context. Applied to Philippians 2:5-11, this would mean that the passage should be read as part of the biblical emphasis on love and humble service, particularly as it is expressed in the Jesus-narrative. We will return to this important step in the next section.

Secondly, also the strength of cultural sensitivity (towards the context of the text as well as the awareness of our own presuppositions) that we have attested to the parameter of countercultural trends needs some qualification. As with parameter (c), it is to be appreciated that parameter $(d)$ pays attention to the dynamics between an ethical text in the Bible and its cultural context. However, as in the case of the other parameters, one needs to bear in mind that identifying a countercultural trend does not set off a hermeneutical mechanism that would automatically confer timeless authority on the countercultural moral that has been discovered (nor does it imply that all cultural conformity is bad). For example, some of the purity laws of the Pentateuch go against the cultural trends of the time, but that does not mean that they must be transferred to today without further reflection. Rather, they need to be heard in the concert of the different canonical voices that relate to the issue. This is also true for the 'liberative' paradigm that has rightly been identified as a dominant voice in the biblical canon. In both parts of the canon, God is portrayed as a model of special compassion for the weak, the poor and the oppressed, for slaves, widows, orphans, and other vulnerable persons and groups. This is one of the paradigms of biblical ethics. A text relating to social issues like these should be read as part of (or in tension with) this paradigm as well as engage in a dialogue with other biblical paradigms before entering the dialogue with contemporary ethics. Moreover, while the critique of suppressive ideologies is clearly countercultural, the amplitude of countercultural voices in the Bible is not limited to this ethical concern (pace Cosgrove 2002:104, 110). Rather, as we have seen at the example of Philippians 2:5-11 (cf. Mt 5:44, etc.), countercultural trends extend over a broader range of ethical attitudes and behaviours. It is this broader panorama of biblical ethics to which we now turn.

\section{Text and canon}

In the previous section we have discussed four parameters that can guide the dialogue between a biblical text and the concerns of contemporary religious-ethical life from the perspective of the cultural context of the text and its relation to the contemporary contexts of the interpreters. As indicated at the outset, situating a biblical text in its cultural context presupposes the established steps of exegesis that include interpreting the text in its literary context. 'Literary context' refers to the immediate literary unit as well as to the respective biblical book (and in some cases also to further writings by the same author). In the present section, we want to broaden our perspective and look at the text not only in its literary and cultural contexts, but also in its canonical context (which may be viewed, biblical-theologically speaking, as a secondary literary context of a biblical passage). The parameters suggested in the previous section take account of the individual voice of the text in its situation and communicative framework. However, in accordance with the title of this article, we are interested in a dialogue between the Bible (in toto) and ethics. The Bible is made up of individual texts and passages, and these need to be related to one another if one wants to see how biblical ethics may inspire ethical living today. The parameters suggested in section 1 should hence be complemented (or even preceded: see the interaction with Hays below) by placing the text in canonical context. In contrast to searching for a particular countercultural trend that one may be able to trace in applying parameter (d), a canonical reading of a passage not only looks for other passages with the same 'liberative spirit' but for any text that relates to the views presented in the passage under consideration. This may uncover innerbiblical consistencies and inconsistencies, overarching narratives and idiosyncratic positions that may or may not stand in tension with one another. The voice of our text will need to be related to the different voices in Scripture, both with a view to a potential canonical consistency on a topic and from the perspective of what may be the dominant voices on, or relating to, a particular topic (canonical centrality). ${ }^{8}$

Before briefly unfolding these two perspectives, ${ }^{9}$ I will clarify my hermeneutical approach by bringing it into conversation with Richard Hays' established model. Hays describes 'The Fourfold Task of New Testament Ethics' as encompassing 1. the descriptive task: reading the text carefully; 2 . the synthetic task: placing the text in canonical context; 3 . the hermeneutical task: relating the text to our situation; and 4. the pragmatic task: living the text (Hays 1997:3-7; cf. the procedure described in the citation from Van der Watt 2006a in the introduction). The methodological moves discussed in section 1 of this article comprise Hays' steps 1 and 3 . We have moved step 2 (which corresponds to section 2 of this article) after steps 1 and 3 because our starting point is not the Bible as a whole but a single biblical passage. We want to make sure that the text itself first gets a proper hearing before it is related to the parameters of canonical consistency and centrality. (Step 4 moves beyond the aims of the current article, but it will be discussed briefly in the conclusion.) The hermeneutical methodology reflected in this article is not a recipe of six principles that will guarantee perfect results if applied in chronological order. Rather, we suggest a 'hermeneutical spiral' (cf. Osborne 2006) with different cycles of reflection for the interpretative space that reading Scripture

8.This process is not what some have proposed as a canonical (re-)interpretation which uncovers an 'enhanced meaning' of a text in its canonical context (for a nuanced discussion, see Wall 1995). Rather, I am suggesting a critical dialogue nuanced discussion, see Wall 1995). Rather, I am suggesting a critical dialogue between different biblical passages interpreted in their immediate literary and emphases provided by other texts.

9.I hope to provide a more detailed discussion in Rabens (2018). In that context a short analysis will be offered of how some of the hermeneutical parameters short analysis will be offered of how some of the hermeneutical parameters
discussed in this article have been utilised by different traditions in the debates over gender roles and homosexuality. 
creates. If one starts with a single text and intends to focus on its particular voice, one may proceed in accordance with the structure of this article from 1. (a-d) to 2. (a-b). However, if one starts more broadly with the aim of tracing the/a moral vision of the New Testament (or of the Bible as a whole), one may proceed as suggested by Hays and those who have refined his model (see the constructive discussions as well as alternative approaches presented in Rabens, Grey \& Kamell Kovalishyn 2018).

\section{a. Canonical diversity and canonical consistency}

An ethical text of the Bible needs to be heard in the choir of biblical voices on a particular issue. In this context, it is essential to acknowledge the polyphonic nature of the Bible as a whole as well as that of some books in particular (such as Lamentations, as Bier 2015 has recently argued). The Bible itself is not silent on such tensions and disagreements as we can see from reports like Galatians 2. As I have argued above, in this way the biblical writings model a process of doing theology. However, on some ethical issues we find a high level of unanimity. The parameter of canonical consistency suggests that (implicit or explicit) ethical models and imperatives which are repeated without significant modifications throughout the Bible (in diverse cultural, social, and historical situations) have more potential to qualify as signposts for Christian ethics today than those that differ in times and places. A good example is the consistent stress on marital faithfulness and prohibition of adultery throughout the Bible.

\section{b. Canonical diversity and canonical centrality}

If the ethical stance of the biblical text that we are engaging is scarcely ever echoed or is even contradicted by other biblical voices on the topic, turning to essential ethical emphases of Scripture can provide further guidance. In fact, as I will argue below, we also need to foster dialogue between ethical viewpoints with a high level of canonical consistency (such as the biblical ban on same-sex intercourse) and those with a high level of canonical centrality (such as the golden rule; $\mathrm{Mt}$ $7: 12$, etc.). The parameter of canonical centrality, then, suggests that ethical narratives and imperatives need to be viewed from the perspective of their dominance and importance in the choir of ethical voices in the Bible. What is the relation of a particular text to the overarching narratives and themes of Scripture, such as God's liberating work in the exodus and in the Christ-event? How does it relate to biblical core images and values such as community, cross and new creation (Hays 1997:193-200), corporate solidarity and otherregard (Horrell 2016), ${ }^{10}$ the motifs of the giving of life, participation and status reversal of 'the strong' and 'the weak', et cetera ${ }^{11}$ ? How does it correspond to or is it even part of central paradigms of biblical ethics as, for example, the

10.Gushee and Stassen (2016:19) single out seven marks of the reign of God deliverance, peace, justice, healing, inclusion in community, joy and God's presence.

11.Theißen (2003) further names the motifs of creation, wisdom, miracle, repentance, Stellvertretung [representation, substitution], indwelling, and the agape motif. hospitable person in the context of the Bible's familial paradigm, God creating community, and suffering with and from his people, et cetera? ${ }^{12}$

It is not necessary to decide on one set of biblical core images and paradigms over against others. However, in accordance with what has been argued above, we need to emphasise again that images and paradigms cannot be reduced to abstract principles. Rather, they are an integral part of the key narratives of Scripture..$^{13}$ In the Hebrew Bible, they are formed and informed by the narrative of God's acting in the creation of the world and in Israel's history. For example, the story of Yhwh, who heard the cries of the slaves in Egypt, stands behind the legal protection of the vulnerable (Ex 22:21-23; Lv 19:33-34, etc.). Such stories should not be reduced to a series of moral exempla [stories with 'a moral'] as this would ignore the complexity and openness characteristic of stories. Rather, these narratives provide for the fact that human ethical inquiry tends to be anchored in specific cases, and that it is through the richness of storytelling that this inquiry comes to understand what it is to be human and to make informed choices in a world that is only partly predictable (cf. footnote 4). Also in the New Testament narrative abounds with a focal point in the Gospels continuing the story of God's people, the covenant and the expected Messiah (cf. Longenecker 2002 on Paul, and Rabens 2017 on Second Temple Jewish ethics). In the epistles, the story of Jesus is then taken as an example to follow (e.g. in Phlp 1:27; 2:5 11; 1 Pt 2:21-23; Heb 12:1-4).

The parameter of canonical centrality needs critical reflection. Its application is extremely complex because it presupposes a broad knowledge and critical appreciation of the biblical canon. It will always reflect the subjective stance of the interpreter. For this reason, some reject this hermeneutical parameter altogether. However, I would counter that every reader of the biblical canon inevitably makes judgements on the text by viewing some narratives and paradigms as more important or central than others. As in any act of interpretation, so also in the case of the process of approaching and attempting to acquire understanding of this large religious library, it is impossible to avoid subjectivity. As a corrective means, we should therefore read the Scriptures (and particularly those parts that we do not like) in dialogue with different and diverse interpretative communities and traditions, and continue to critically reflect on our presuppositions and motivations, particularly when our

12.Compare Berg 1993:78-87; Janzen 1994. Paradigms are here understood as personally and holistically conceived images of a model (e.g. a wise person, good king) that imprint themselves non-conceptually on the characters and actions of those who hold it (Janzen 1994:27-28; cf. Rabens 2016b:5-6). For further concepts relating to canonical centrality, see the discussion of 'trajectories' in 1.d).

13.Postmodernists have rejected overarching metanarratives as being inherently oppressive and authoritarian. By way of response, $\operatorname{Luz}(2014: 99-147,558)$ has made the helpful suggestion that we should rather speak of 'small metanarratives'. Moreover, Flemming (2005) argues that

the grand narrative of the Bible, far from being an instrument of oppression, is a story of a story of a compassionate God who repeatedly chooses and uplifts the lowly, a story that is centered in the humility, shame and vulnerability of the cross (1 Co 1:18-2:3; Phil 2:6-8). A message for a postmodern culture will invite people to see the world through the biblical story and to allow that story to reshape thei lives. It will also lead us to communicate the gospel through telling our own stories - with vulnerability and integrity - as witness to the experience of the compassion and transforming grace of God. (p. 317) 
reading seems to provide us with material that reinforces what we already think.

Several biblical voices demonstrate how the parameter of canonical centrality can work in practice. Some biblical paradigms are given special prominence; some are used for critical reflection on other traditions. For example, justice, mercy and loving kindness are emphasised over against the iconic trends of the priestly tradition (Hs 6:6; Mi 6:7-8; Mt 9:13; 12:7; cf. footnote 7). In Matthew's Gospel, Jesus criticises the Pharisees for tithing herbs but neglecting 'the weightier matters of the law: justice and mercy and faith. It is these you ought to have practiced without neglecting the others' (Mt 23:23). Central strands of biblical ethics can thus be valued over others (Güterabwägung), serve as correctives or even lead to the marginalisation of variant ethical notions (cf. Jesus healing on the Sabbath: Mt 12:7-13; Paul suggesting that not causing a brother or sister to stumble is a higher good than culinary freedom: 1 Cor 8:9, Rm 14:15-21; Paul favouring celibacy over marriage: 1 Cor 7:36-38; cf. Zimmermann 2016:171-172, 254-256).

I have repeatedly argued that the multiple narratives and paradigms of biblical ethics should not be reduced to single principles. This critique was also applied to the use of 'love' by the situation ethicists mentioned in the introduction. Nevertheless, various voices in Scripture identify love as the essence of biblical ethics. It is the summary and fulfilment of the law, not its abolition (Dt 6:4-6; Mk 12:28-34; Mt 22:36-40; Lk 10:25-28; Rm 13:8-10; Gl 5:6, 14; Ja 2:8; cf. Lv 19:18; 1 Cor 12:31-13:13; Jn 13:34-35; 1 Jn 4:7-21, etc.; cf. Wischmeyer 2015; Rabens 2012a:120-133; Rabens 2016a:568-573; et al.). ${ }^{14}$ The double command of love may hence be viewed as the very backbone of biblical ethics in toto from the perspective of canonical consistency and particularly from the perspective of centrality. Together with justice and mercy (Mc 6:8; cf. Ex $34: 6-7$; etc.), it has the potential of functioning as a critical reference for evaluating both intra- and extra-biblical ethical claims. In the Bible, love is not a vapid empty shell, but derives its character from being rooted in the narrative of God's acting in the history of his people. It is embedded in the story of creation, fall, covenant(s) and, most fundamentally, the life, death and resurrection of Jesus Christ. Jesus Christ is love incarnate (thus e.g. Jn 3:16; 1 Jn 3:16; cf. Luz 2014:553555). As the biblical narrative reaches a climax in the Christstory (cf. Van der Watt 2006a:615-616), Christ should be the inspiration and focal point of our theology and ethics. Along these lines, Martin Luther proposed that everything should be judged from the perspective of whether it advances and promotes Christ and coheres with the gospel (cf. WA.DB $7 ; 384,25-32$ ). The potential input of a biblical text for our dialogue between Scripture and ethics today should hence be discerned in the light of the cruciform and anastiform narrative of Jesus Christ in (and continuing beyond) the Bible. As Barton (2016) puts it,

\footnotetext{
14. Hays' resistance to love as a focal image stems mainly from his concern that love is not equally emphasised across all New Testament writings (Hays 1997:200-203). In his synthetic task he thus seems to give priority to quantity over quality. However, his synthetic task he thus seems to give priority to quantity over quality. However,
as our (rather incomplete) list shows, numerous biblical texts explicitly give centre stage to love as a summary of biblical ethics.
}

what we must hold on to, and make the touchstone for all that we think and do, is the gospel of the crucified and risen Christ as the revelation of the saving wisdom of God. Such a gospel is judgement on cultures of oppression and all that is death-dealing - however entrenched in religion and rooted in scriptural texts they may be. But that same gospel is also the power of God bringing resurrection life, and drawing us, by the Spirit's guidance, into patterns of sociality that are life-giving. (p. 169)

The narrative of Christ's embodiment of love shares the complexity and openness characteristic of stories without becoming arbitrary. We can see this from the different aspects of the Christ-story that the authors of the epistles draw out for different purposes. Luz (2014:556) therefore calls for a christologically guided, pluralistic reading of the New Testament. This undertaking, which will involve the creative imitation of Jesus' example (cf. Bennema 2017:7.3.1.), calls for an integrative act of imaginative improvisation (placing one's community's life imaginatively within the world articulated by the texts) and can inspire metaphor-making (Hays 1997:310; Rowe 2013). Through the experience and the narrative of love, interpreters of (ethical) texts of Scripture may be drawn into the world of the story and get reshaped by it - particularly through the promised action of the Holy Spirit. $^{15}$

\section{Conclusion}

Interpreting Scripture with a view to dialogue with ethical concerns of today is a complex but fascinating adventure. In this article I have provided some guidelines that can help us on this exciting path. I have discussed the task of 1 . Situating an ethical text in its cultural context from the perspectives of (a) Cultural particulars and underlying purpose, (b) Analogies between ancient and contemporary cultures, (c) Cultural conformity and cultural limitation, and (d) Cultural and countercultural trends; and we have investigated the task of 2. Situating an ethical text in its canonical context from the perspectives of (a) Canonical consistency, and (b) Canonical centrality. From the perspective of canonical centrality, I have argued that the biblical narrative of love, as it culminates in the gospel of Jesus Christ, stands out as a primus inter pares reference point for the dialogue between biblical ethics and ethics today. ${ }^{16}$

The pathways between the biblical text and our questions today move us back and forth between the participants in this open dialogue. In our quest for meaning and profound understanding of the text in its cultural embeddedness and of ourselves and our cultural conditioning, our engagement

\footnotetext{
15.Compare footnote 13. On the notion of experience in the context of interpretation see Rabens (2012b:138-145).

16.As Luz (2014) points out, Jesus Christ, as he is portrayed in the biblical narrative as an embodiment of love, invites dialogue:

Die gemeinsame Bezugsperson Jesus macht einen Dialog zwischen den vielen, die sich in unterschiedlicher Weise auf ihn berufen, nötig und möglich. - Die Liebe, die durch die Geschichte von Jesus Christus bewirkt wird, ist auf Lialo die durch die Geschichte von Jesus Christus bewirkt wird, ist auf Dialog angewiesen: Liebe verfügt nicht über jederzeit gültige Rezepte; nur durch Kommunikation lässt sich herausfinden, was in einer konkreten Situation Liebe ist. [Jesus as the common person of trust requires and enables dialogue between the many who refer to him in different ways. - The love that is effected throug the story of Jesus Christ is dependent on dialogue: love does not have universally applicable recipes at its disposal; one can only find out through communication what love means in a given situation.] (p. 554 [author's translation])
} 
with both perspectives should lead to a process of mutual enlightenment that will prevent us from conceiving the dialogue as a one-way street from the text to today. In the present article, however, our perspective on the dialogue was focused on this very direction, because our question is how one may enter the dialogue when starting from a particular (ethical) text in Scripture. Nevertheless, it is also possible to enter the dialogue by starting with ethical questions from today's world. These may or may not find explicit dialogue partners in Scripture - we may think of such diverse topics as business ethics, family ethics, the ethics of preimplantation genetic diagnosis or ecological ethics (on the latter see, for example, the hermeneutical reflections in Horrell 2018). In each case one will need to set up a dialogue with the central biblical paradigms and narratives that are (closely or more remotely) related to the issue (cf. Jesus starting with the Bible's positive teaching on marriage when asked about divorce Mk 10:2-9; Mt 19:3-9) and apply, where appropriate, the parameters of hermeneutical analysis discussed in this article.

Another step on the pathway of dialogue that may provide further insights into the hermeneutical dynamics relating to the interpretation of a particular ethical text is what Hays calls (4.) 'the pragmatic task: living the text'. Trying to live according to the text (with the overall aim of 'produc[ing] persons and communities whose character is commensurate with Jesus Christ and thereby pleasing to God' $)^{17}$ will raise new questions and perspectives that one may then readdress to the text. This dialogue is only possible if one is ready to say goodbye to the myth of objective interpretation by the disentangled and uninvolved interpreter. However, insisting that 'there can be no true understanding apart from lived obedience' (Hays 1997:7, 310; 2006:16) seems to move towards an exclusiveness at the opposite end. The practice of Scripture-shaped imagination, improvisation and performance of the text may find its place in Jewish or Christian interpretative communities like synagogues, churches or some theological seminaries. However, it is usually not part of the curriculum of academic study of the Bible and religion in the university context. It is good that these different scenarios of interpretation exist, for no-one should be forced into any kind of 'performance of the text' in order to have a voice in the (academic) discourse on the interpretation of the text and its potential relevance for today.

For the pathways of interpretation suggested in this article we need diverse dialogue partners. Biblical scholars need to converse with systematic theologians, natural and social scientists, lawyers and many others. We will need military officers and peace campaigners to sit down and discuss biblical material about war and violence together, and include both bankers and anti-capitalist activists or campaigners for

17. Hays 1997:7. This is also a key feature of the 'Theological Interpretation of Scripture' proposed by Fowl (2009) and others. Compare Gorman (2009:149), who explains that 'the theological interpreter, sensitive to the Scriptures as a vehicle of divine address, seeks to hear the voice of God through the human voices; the divine address, seeks to hear the voice of God through the human voices; the limit the significance of texts to the results of diachronic and synchronic study'. This surplus, which is attributed to the divine author, is then interpreted in light of th basic theological convictions and confessional expressions (esp. the 'rule of faith') of Christian reading communities (for discussion, see for example, Turner 2000:44 70; Klink III \& Lockett 2012:179-182). the poor when considering financial issues. Only an open and inclusive interpretative dialogue has the potential to help to protect against authoritarian and self-serving community readings such as colonialist or Nazi interpretations. Such a dialogical reading of ethical texts in Scripture will need to be set alongside other sources of moral guidance such as reason, tradition and experience as well as all our modern resources from the human sciences, medicine, psychology, et cetera (cf. Burridge 2007:395). The views which emerge need to be critically (and, in the religious context, prayerfully) reflected by listening to the experience of others - especially of those who have been victimised and silenced by particular interpretations and performances of Scripture throughout (church) history.

As we have seen, the Bible does not provide ethical blueprints for us to copy or clear-cut techniques of ethical application for us to adopt. Scripture's role is more formational (of character) than adjudicative (of issues). We are offered orientations, narratives, models, types, paradigms and inspirations - elements permitting us to acquire, on our own initiative, a 'hermeneutic competency' and thus the capacity to judge (cf. Rowland \& Roberts 2008:59-60). Practicing such discernment is a challenge and will remain subjective. Searching for absolute certainty in this endeavour like Bishop Hopkins and others would mean chasing a shadow. Nevertheless, the apostle Paul promises that Christians are not left alone in the task of ethical discernment. Rather, as the body of Christ they 'have the mind of Christ' (1 Cor 2:16; cf. Phlp 2:5). This very fact should provide us with a more optimistic attitude towards our own hearts, inclinations and feelings, as we corporately let our imagination be shaped by Scripture and listen to what the Spirit has been saying to the churches throughout history (cf. church tradition[s] and the embodiment of the Christ-story in the lives of the saints) and is saying today (cf. $\mathrm{Rv} 2: 7,11,17,29 ; 3: 6,13,22 ; \mathrm{Jn} 16: 12-14$ ).

\section{References}

Barton, S.C., 2016, 'Marriage, family, the Bible and the gospel', Theology 119, 163-171. https://doi.org/10.1177/0040571X15623690

Bennema, C., 2017, Mimesis in the Johannine literature: A study in Johannine ethics, Bloomsbury T\&T Clark, New York. (LNTS 498).

Berg, H.K., 1993, Grundriss der Bibeldidaktik: Konzepte, Modelle, Methoden, Kösel/ Calwer, München. (Handbuch des biblischen Unterrichts, 2).

Bier, M., 2015, 'Perhaps there is hope': Reading Lamentations as a polyphony of pain, penitence, and protest, T\&T Clark, London. (LHBOTS 603).

Boff, C., 1987, Theology and praxis: Epistemological foundations, Orbis, Maryknoll.

Brueggemann, W., 2005, Theology of the Old Testament: Testimony, dispute, advocacy, Fortress, Minneapolis.

Burridge, R.A., 2007, Imitating Jesus: An inclusive approach to New Testament ethics, Eerdmans, Grand Rapids.

Cosgrove, C.H., 2002, Appealing to Scripture in moral debate: Five hermeneutical rules, Eerdmans, Grand Rapids.

Cosgrove, C.H., 2011, 'Scripture in ethics: A history', in J.B. Green (ed.), Dictionary of Scripture and ethics, pp. 13-25, Baker Academic, Grand Rapids.

Duvall, J.S. \& Hays, J.D., 2005, Grasping God's Word: A hands-on approach to reading, interpreting, and applying the Bible, 2nd edn., Zondervan, Grand Rapids.

Finnern, S. \& Rüggemeier, J., 2016, Methoden der neutestamentlichen Exegese: Ein Lehr- und Arbeitsbuch, Francke, Tübingen. (utb 4212).

Flemming, D.E., 2005, Contextualization in the New Testament: Patterns for theology and mission, IVP, Downers Grove.

Fletcher, J., 1966, Situation ethics: The new morality, Westminster, Philadelphia.

Fowl, S.E., 2009, Theological interpretation of Scripture, Cascade, Eugene. (Cascade Compannions). 
Frevel, C., 2015, 'Orientierung! Grundfragen einer Ethik des Alten Testaments', in C. Frevel (ed.), Mehr als zehn Worte? Zur Bedeutung des Alten Testaments in Frevel (ed.), Mehr als zehn Worte? Zur Bedeutung
ethischen Fragen, pp. 9-57, Herder, Freiburg. (QD 273).

Goldingay, J., 2018, 'The two Testaments as an ethical resource', in V. Rabens, J. Grey \& M. Kamell Kovalishyn (eds.), New approaches to biblical ethics, Brill, Leiden. (BINS). [forthcoming]

Gorman, M.J., 2009, Elements of biblical exegesis: A basic guide for students and ministers, 2nd edn., Hendrickson, Peabody.

Green, J.B., 2007, 1 Peter, Eerdmans, Grand Rapids. (THNTC).

Gushee, D.P. \& Stassen, G.H., 2016, Kingdom ethics: Following Jesus in contemporary context, 2nd edn., Eerdmans, Grand Rapids.

Harrill, J.A., 2006, Slaves in the New Testament: Literary, social, and moral dimensions, Fortress Press, Minneapolis.

Hays, R.B., 1997, The moral vision of the New Testament: Community, cross, new creation: A contemporary introduction to New Testament ethics, T\&T Clark, Edinburgh.

Hays, R.B., 2006, 'Mapping the field: Approaches to New Testament ethics', in J.G. van der Watt (ed.), Identity, ethics and ethos in the New Testament, pp. 3-19, De Gruyter, Berlin/New York. (BZNW 141).

Horrell, D.G., 2016, Solidarity and difference: A contemporary reading of Paul's ethics, 2nd edn., Bloomsbury T\&T Clark, London.

Horrell, D.G., 2018, 'The moral vision of the Bible: A New Testament approach', in V. Rabens, J. Grey \& M. Kamell Kovalishyn (eds.), New approaches to biblical ethics, Brill, Leiden. (BINS). [forthcoming]

Janzen, W., 1994, Old Testament ethics: A paradigmatic approach, Westminster/John Knox Press, Louisville.

Klink E.W. III, \& Lockett, D.R. (eds.), 2012, Understanding biblical theology: A comparison of theory and practice, Zondervan, Grand Rapids.

Loader, W., 2016, 'Homosexuality and the Bible', in P. Sprinkle (ed.), Two views on homosexuality, the Bible, and the church, pp. 17-48, 66-68, Zondervan, Grand Rapids. (Counterpoints: Bible and Theology).

Longenecker, B.W. (ed.), 2002, Narrative dynamics in Paul: A critical assessment, Westminster John Knox Press.

Luz, U., 2014, Theologische Hermeneutik des Neuen Testaments, Neukirchene Theologie, Neukirchen-Vluyn.

Marshall, I.H., 2004, Beyond the Bible: Moving from Scripture to theology. With essays by Kevin J. Vanhoozer and Stanley E. Porter, Baker/Paternoster, Grand Rapids/ Milton Keynes. (ASBT)

Meadors, G.T. (ed.), 2009, Four views on moving beyond the Bible to theology Zondervan, Grand Rapids. (Counterpoints: Bible and Theology).

Meyers, C., 2013, Rediscovering Eve: Ancient Israelite women in context, Oxford University Press, New York.

Moxnes, H., 1993, 'New Testament ethics - universal or particular? Reflections on the use of social anthropology in New Testament studies', ShTh 47, 153-168.

Osborne, G.R., 2006, The hermeneutical spiral: A comprehensive introduction to biblical interpretation, 2nd edn., IVP, Downers Grove.

Rabens, V., 2012a, 'Johannine perspectives on ethical enabling in the context of Stoic and Philonic ethics', in J. van der Watt \& R. Zimmermann (eds.), Rethinking the and Phics of John: "Implicit Ethics" in the Johannine writings, pp. 114-139, Mohr ethics of John: "Implicit Ethics" in the Johannine Writings, pp. 114-139, Mohr and Norms of New Testament Ethics III, WUNT I/291).

Rabens, V., 2012b, 'Power from in between: The relational experience of the Holy Spirit and spiritual gifts in Paul's churches', in I.H. Marshall, V. Rabens \& C. Spirt and spitual gifts in Paul's churches', in I.H. Marshall, $V$. Rabens \& C. theology: Essays in honor of Max Turner, pp. 138-155, Eerdmans, Grand Rapids.

Rabens, V., 2014, “Indicative and Imperative" as the substructure of Paul's theology and-ethics in Galatians? A discussion of divine and human agency in Paul', in M.W. Elliott, S.J. Hafemann, N.T. Wright \& J. Frederick (eds.), Galatians and theology: Justification, the gospel, and ethics in Paul's Letter, pp. 285-305, Baker Academic, Grand Rapids.
Rabens, V., 2016a, 'The faithfulness of God and its effects on faithful living: A critical analysis of Tom Wright's Faithfulness to Paul's Ethics', in C. Heilig, J.T. Hewitt \& M.F. Bird (eds) God and the faithfulness of Paul: A critical examination of the Pauline theology of NT. Wright pp 555-580, Mohr examination of the Pauline theolog
Siebeck, Tübingen. (WUNT II/413).

Rabens, V., 2016b, 'Review of Robert L. Brawley (ed.), The Oxford Encyclopedia of the Bible and Ethics', Review of Biblical Literature 11, 1-6.

Rabens, V., 2017, 'Ethics', in L.T. Stuckenbruck \& D.M. Gurtner (eds.), The T\&T Clark encyclopaedia of Second Temple Judaism, T\&T Clark International, London. [forthcoming]

Rabens, V., 2018, 'Inspired by the Text!? Hermeneutical suggestions for the dialogue between biblical texts and contemporary ethics', in V. Rabens, J. Grey \& M. Kamell Kovalishyn (eds.), New approaches to biblical ethics, Brill, Leiden. (BINS). [forthcoming]

Rabens, V., Grey, J. \& Kamell Kovalishyn, M. (eds.), 2018, New approaches to biblical ethics, Brill, Leiden. (BINS). [forthcoming]

Rowe, C.K., 2013, “'Do you understand what you are reading?" The formation of a scriptural imagination', Divinity 12(2), 5-9.

Rowland, C. \& Roberts, J., 2008, The Bible for sinners: Interpretation in the present time, SPCK, London.

Strauss, M.L., 2009, 'Reflections on moving beyond the Bible to theology', in G.T. Meadors (ed.), Four views on moving beyond the Bible to theology, pp. 271-298, Zondervan, Grand Rapids. (Counterpoints: Bible and Theology).

Theißen, G., 2003, Zur Bibel motivieren: Aufgaben, Inhalte und Methoden einer offenen Bibeldidaktik, Kaiser, Gütersloher Verlag-Haus, Gütersloh.

Thrall, M.E., 2000, A critical and exegetical commentary on the second epistle to the Corinthians: Vol. 2 Commentary on II Corinthians VIII-XIII, T\&T Clark, Edinburgh. (ICC).

Turner, M., 2000, 'Historical criticism and theological hermeneutics of the New Testament', in J.B. Green \& M. Turner (eds.), Between two horizons: Spanning New Testament studies and systematic theology, pp. 44-70, Eerdmans, Grand Rapids.

Van der Watt, J.G., 2006a, 'Again: identity, ethics, and ethos in the New Testament: A few tentative remarks', in J.G. van der Watt (ed.), Identity, ethics, and ethos in the New Testament, pp. 611-632, De Gruyter, Berlin/New York. (BZNW 141).

Van der Watt, J.G. (ed.), 2006b, Identity, ethics, and ethos in the New Testament, De Gruyter, Berlin/New York. (BZNW 141).

Van der Watt, J.G., 2018, 'Reading the New Testament from an Ethical Perspective: A Comprehensive Approach', in V. Rabens, J. Grey \& M. Kamell Kovalishyn (eds.) New Approaches to Biblical Ethics, Brill, Leiden. (BINS). [forthcoming]

Wall, R.W., 1995, 'Reading the New Testament in canonical context', in J.B. Green (ed.), Hearing the New Testament: Strategies for interpretation, pp. 370-393, Paternoster Press/Eerdmans, Carlisle/Grand Rapids.

Webb, W.J., 2001, Slaves, women and homosexuals: Exploring the hermeneutics of cultural analysis, IVP, Downers Grove.

Wischmeyer, O., 2015, Liebe als Agape: Das frühchristliche Konzept und der moderne Diskurs, Mohr Siebeck, Tübingen.

Zimmermann, R., 2009, 'The “Implicit Ethics” of New Testament Writings: A draft on a new methodology in analysing New Testament ethics', Neotestamentica 43, 398-422.

Zimmermann, R., 2013, 'Pluralistische Ethikbegründung und Normenanalyse im Horizont einer "impliziten Ethik" frühchristlicher Schriften', in F.W. Horn, U. Volp \& R. Zimmermann (eds.), Ethische Normen des frühen Christentums: Gut Leben - Leib - Tugend, pp. 3-28, Mohr Siebeck Tübingen (Kontexte und Leben - Leib - Tugend, pp. 3-28, Mohr Siebeck, Tubingen. (Kontexte und Normen neutestamentic
Ethics IV, WUNT I/313).

Zimmermann, R., 2016, Die Logik der Liebe: Die 'implizite Ethik' der Paulusbriefe am Beispiel des 1. Korintherbriefs, Neukirchener Theologie, Neukirchen-Vluyn. (BThSt, 162).

Zimmermann, R., 2018, 'How to read biblical texts ethically: The new method of "Implicit Ethics" in dealing with biblical ethics', in V. Rabens, J. Grey \& M. Kamel Kovalishyn (eds.), New Approaches to Biblical Ethics, Brill, Leiden. (BINS). [forthcoming] 